\title{
Review of evidence for genetic testing for CYP450 polymorphisms in management of patients with nonpsychotic depression with selective serotonin reuptake inhibitors
}

Mugdha Thakur, $M D^{1}$, Iris Grossman, $P h D^{2}$, Douglas C. McCrory, $M D, M H S^{3}$, Lori A. Orlando, MD, $M H S^{3}$, David C. Steffens, MD, MHS ${ }^{1}$, Kathryn E. Cline, MHS $S^{3}$, Rebecca N. Gray, DPhil ${ }^{3}$, Jennifer Farmer, $D^{1}$, Georgette DeJesus, $\mathrm{MD}^{1}$, Cara O’Brien, $M D^{3}$, Gregory Samsa, $P h D^{3}$, David B. Goldstein, $P h D^{2}$, and David B. Matchar, $M D^{3,4}$

\begin{abstract}
Purpose: Cytochrome P450 (CYP450) enzymes metabolize selective serotonin reuptake inhibitor (SSRI) drugs used in treatment of depression. Variants in these genes may impact treatment efficacy and tolerability. The purpose of this study was 2-fold: to systematically review the literature for evidence supporting CYP450 genotyping to guide SSRI treatment for major depression, and, where evidence is inadequate, to suggest future research. Methods: We searched MEDLINE ${ }^{\circledR}$ and other databases for studies addressing five key questions suggested by the Evaluation of Genomic Applications in Practice and Prevention Working Group. Eligibility criteria were defined, and studies were reviewed independently by paired researchers. A conceptual model was developed to guide future research. Results: Review of 1200 abstracts led to the final inclusion of 37 articles. The evidence indicates relatively high analytic sensitivity and specificity of tests detecting a subset of polymorphisms of CYP2D6, 2C19, 2C8, 2C9, and 1A1. We found marginal evidence regarding a clinical association between CYP450 variants and SSRI metabolism, efficacy, and tolerability in the treatment of depression. Conclusions: Current evidence does not support the use of CYP450 genotyping to guide SSRI treatment of patients with depression. Studies are proposed that will effectively guide decision-making in the area of CYP450 testing in depression, and genetic testing more generally.
\end{abstract}

Genet Med 2007:9(12):826-835.

Key Words: SSRI, depression, pharmacogenetics, CYP450, evidence-based medicine

Major depressive disorder (MDD) is widely distributed in the population ${ }^{1}$ and is associated with severe symptoms and functional impairment. Worldwide, depression is the fourth leading cause of disease burden, in terms of impact on disability-adjusted survival, and the leading cause of nonfatal burden. ${ }^{2}$ For individuals who respond to antidepressant drugs, the results can be signif-

\footnotetext{
From the ${ }^{1}$ Department of Psychiatry and Behavioral Sciences, Duke University Medical Center, Durham, North Carolina; ${ }^{2}$ IGSP Center for Population Genomics and Pharmacogenetics, Duke University, Durham, North Carolina; ${ }^{3}$ Duke Center for Clinical Health Policy Research, Durham, North Carolina; and ${ }^{4}$ Department of Veterans Affairs Medical Center, Durham, North Carolina.

Mugdha Thakur, MD, Department of Psychiatry and Behavioral Sciences, Duke University Medical Center,DUMC Box 3399,Durham, NC27710.E-mail: thaku001@mc.duke.edu.

The manuscript is based on an evidence report prepared by the Duke Evidence-Based Practice Center (EPC) for the Agency for Healthcare Research and Quality (AHRQ). The authors of this report are responsible for its content. Statements in the report should not be construed as endorsement by the Agency for Healthcare Research and Quality or the US Department of Health and Human Services.
}

Disclosure: The authors declare no conflict of interest.

Submitted for publication July 27, 2007.

Accepted for publication September 19, 2007.

DOI: $10.1097 /$ GIM.0b013e31815bf98f icant; however, response rates can be as low as $50 \%,{ }^{3}$ making depression one of the biggest challenges in health care.

Selective serotonin reuptake inhibitors (SSRIs) have become first-line therapy for MDD. Compared with older therapies, such as the tricyclic antidepressants, SSRIs are better tolerated and safer in overdosage, which is an important consideration when treating depressed patients who may become suicidal. However, SSRIs are not without drawbacks. SSRI treatment of MDD is associated with delayed response, typically starting after 2-4 weeks of treatment, high rates of nonresponse (up to $50 \%)$, and discontinuation secondary to poor tolerability (12\%). ${ }^{4,5}$ Currently, there are no generally accepted strategies for SSRI selection in individual patients, and less than optimal selection approaches may contribute to low efficacy and increased risk of side effects. Evaluation of blood concentration of SSRIs and metabolites has not been helpful, as there is no established relationship between blood concentration and clinical response to SSRIs at usual doses ${ }^{6-17}$; nor has any threshold been identified that defines toxic concentrations. Thus, there has been interest in diagnostic biomarkers, such as genetic markers, which could guide treatment decisions at the outset of therapy. 
The cytochrome P450 (CYP450) enzymes-primarily CYP2D6, CYP2C19, and CYP2C9-are involved in the metabolism of virtually all SSRIs. ${ }^{18}$ It is important to note that enzymes other than CYP are also involved in SSRI metabolism, ${ }^{19,20}$ and for a given SSRI, more than one CYP enzyme may be involved in its metabolism. ${ }^{21,22}$ Genetic polymorphisms have been identified for most of the CYP450 enzymes that decrease their activity, including alleles causing complete loss of function (also called deficiency alleles). Individuals carrying combinations of decreased activity alleles are referred to as intermediate metabolizers (IMs), and individuals homozygous or compound heterozygous for the deficiency alleles are defined as poor metabolizers (PMs), reflecting the extent of decrease in activity. Alleles carrying multiple copies of functional genes, on the other hand, lead to increased enzyme activity, with individuals expressing these multiple alleles termed ultrarapid metabolizers (UMs). The majority of individuals, carrying two functionally active alleles, are referred to as extensive metabolizers (EMs). Phenotypically, these classifications translate into differing rates of metabolism of a variety of drugs, potentially leading to toxicity or lack of efficacy in non-EM patients. There are considerable frequency differences across ethnic groups reported for some of the known CYP2D6 polymorphisms. For example, approximately $7 \%$ of Caucasians are CYP2D6 PMs, whereas only $1-2 \%$ of Asians and $2-4 \%$ of African Americans are PMs. ${ }^{23}$ In contrast, $10 \%$ of southern Europeans exhibit duplication of the CYP2D6 gene, which is associated with the ultra-rapid phenotype. Moreover, some genetic polymorphisms result in differential functional activity, depending on the combination of the metabolized drug and ethnic origin of a given carrier. ${ }^{24,25}$

Several SSRIs are potent inhibitors of some CYP450 enzymes; for example, CYP2D6 activity is substantially inhibited by fluoxetine and paroxetine. This inhibition can raise serum concentrations of other drugs metabolized by that enzyme, increasing the likelihood or severity of drug-drug interactions. This phenomenon is of great importance, as SSRIs are commonly prescribed to patients with medical comorbidities and are prescribed in conjunction with multiple other medications.

In this context, there is increasing interest in the potential role of CYP450 genetic polymorphisms as markers guiding SSRI management in clinical practice, ${ }^{18,26,27}$ particularly with the commercial availability of diagnostic tools depicting patients' genotypes in key drug-metabolizing enzymes. A significant recent development was the approval by the US Food and Drug Administration (FDA) of the Roche AmpliChip ${ }^{\circledR}$ CYP450 Test for this purpose. ${ }^{28}$ The AmpliChip delivers the results of testing for CYP2D6 and CYP2C19 polymorphisms in the form of "predicted phenotypes," classifying test subjects as PMs, IMs, EMs, or UMs.

It remains unclear whether sufficient evidence exists to support the utility of such genetic tests in routine clinical practice (I. Grossman, unpublished data). The objective of this study was to systematically and critically review the available literature, using standard methods of evidence-based medicine to inform current decisions about the use of CYP450 genetic test- ing in the treatment of MDD with SSRIs, and to guide research priorities in service to optimal patient care.

\section{MATERIALS AND METHODS}

The primary source of literature was MEDLINE ${ }^{\circledR}$ (1966 to May 2006). Additional databases searched included the Cochrane Database of Abstracts of Reviews of Effectiveness, PsychInfo, HealthSTAR, and CINAHL. Searches of these databases were supplemented by reviews of the reference lists contained in all included articles and in relevant review articles. We also included data from the FDA Website describing the operating characteristics of the Roche AmpliChip CYP450 Test. ${ }^{29,30}$ The basic search strategy used the National Library of Medicine's Medical Subject Headings key word nomenclature developed for MEDLINE. Paired researchers from the Duke research team independently reviewed all abstracts and excluded abstracts if they referred to a single case, examined SSRI inhibition of CYP enzymes (unless the study examined how this is related to genotype), or if the study was found to be outside the scope of the report. An abstract was included for further review if at least one of the paired reviewers recommended that it be included.

At the full-text review stage, paired researchers independently abstracted the articles. When two reviewers returned different decisions about whether to include or exclude an article, they were asked to reconcile the difference. Inclusion and exclusion criteria are described in detail elsewhere. ${ }^{31}$ The methodological approach adopted was designed to address each component relevant to future formulation of evidencebased recommendations by the Evaluation of Genomic Applications in Practice and Prevention (EGAPP) Working Group for the use of genetic testing in depression treatment decisionmaking. To this end, we jointly developed an analytic framework (Fig. 1) that depicts the context in which each of the following key questions should be considered (detailed questions are described elsewhere ${ }^{31}$ ):

1. What is the analytic validity of tests that identify key CYP450 polymorphisms? We included studies reporting tests used for CYP450 genotyping compared either with DNA sequencing (gold standard) or with traditional methods, such as polymerase chain reaction and restriction fragment length polymorphism (PCR-RFLP) and allele-specific PCR (also referred to as allele-specific amplification). The analysis included the Amplichip microarray (Roche), as it met our inclusion criteria. ${ }^{29,30} \mathrm{In}$ keeping with the clinical diagnostic test literature, nonstandard methods are referred to here as reference standards, acknowledging that they provide a lower level of evidence.

2. How well do particular CYP genotypes predict metabolism of particular SSRIs? Because of the overall paucity of data, we included studies that had diagnoses other than nonpsychotic depression as an indication for SSRI treatment, as clinical outcomes in such scenarios may be indicative 


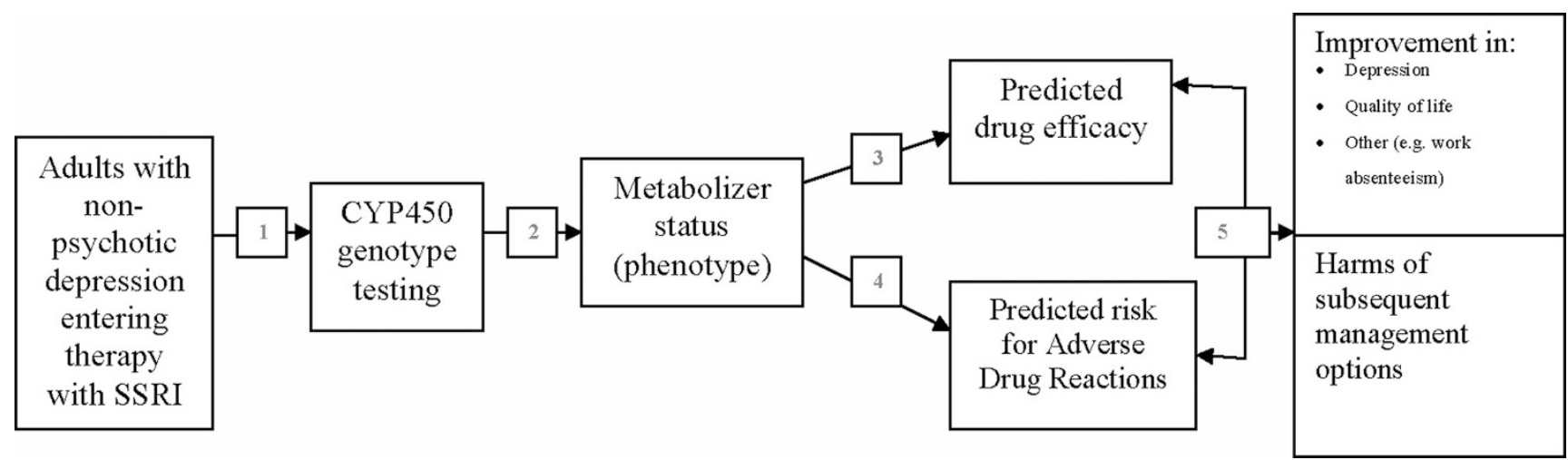

Fig. 1. Analytic framework for evidence gathering on CYP450 genotyping test for SSRI treatment of depression. Numbers refer to the key questions addressed in the report (see Materials and Methods).

of genotype effects. We also included studies in which only a subgroup of patients was treated with SSRIs, and others were treated with other antidepressants, including tricyclic antidepressants. Studies were included irrespective of the method used for genotyping.

3. How well does CYP450 testing predict drug efficacy?

4. How well does CYP450 testing predict adverse drug reactions?

5. Does the identification of the CYP450 genotypes in adults entering SSRI treatment for nonpsychotic depression lead to improved clinical outcomes compared with not testing?

Each included article was evaluated for methodological quality. For the question regarding analytic validity, we assessed quality of studies based on questions in the "Analytic validity, Clinical validity, Clinical utility, and associated Ethical, legal, and social implications" model for evaluation of genetic testing. ${ }^{32}$ For all other questions for which we could identify data, we elected to use the criteria developed by the Oxford Centre for Evidence-Based Medicine ${ }^{33}$ to evaluate individual studies based on type of study (therapy versus prognosis versus prevalence) and strength of study design, with numerical scores ranging between 1 and 5 (including 1a, 1b, 1c, 2a, 2b, 2c, $3 \mathrm{a}, 3 \mathrm{~b}, 4,5$ ), where level 1 includes randomized controlled trials or systematic reviews of randomized controlled trials, and higher levels indicate progressively poorer quality, such that level 5 indicates expert opinion without critical appraisal. The overall strength of recommendation for each question was then graded for each question as A, B, C, or D according to criteria that take into account the quality of individual studies identified for each question, where $\mathrm{A}$ indicates consistent level 1 studies, $\mathrm{B}$ and $\mathrm{C}$ are intermediate quality, and $\mathrm{D}$ indicates level 5 evidence or troublingly inconsistent evidence.

Results for analytic sensitivity and specificity are presented for the most relevant CYP450 enzymes to SSRI metabolism (CYP2D6, 2C19, and 2C9). Detailed results related to all components of analytical validity assessment (sensitivity, specificity, laboratory quality control, and assay robustness), as well as CYP2C8 and CYP1A1 assay evaluation, are presented elsewhere. ${ }^{31}$ All calculations were performed using FastPro version 1.8 (Academic Press, 1992).
It is notable that the definitions of sensitivity and specificity above are most directly applicable to tests with dichotomous results (mutation present or absent). Because there are multiple CYP450 polymorphisms that can be assessed, and each study may provide information on only a subset of polymorphisms, we defined analytic sensitivity operationally as the proportion of known genotype challenge samples that are correctly identified by the test under evaluation. Similarly, analytic specificity was defined operationally as the proportion of known wild-type challenge samples that are correctly identified by the test under evaluation.

\section{RESULTS}

\section{Literature search}

A total of 1200 abstracts were identified, of which 140 met criteria for full-text evaluation. Thirty-seven articles met the final inclusion criteria and pertained to the questions above. The interrater agreement for inclusion of abstracts (kappa statistic) ranged from -0.037 to $0.613 .{ }^{34}$

\section{Results by question}

Question 1: What is the analytic validity of genetic tests that identify key CYP450 polymorphisms?

CYP2D6. We identified nine reports that compared clinical methods for genotyping CYP2D6 polymorphisms to a reference standard. Of these, only two ${ }^{29,35}$ provided a comparison with the gold standard, DNA sequencing (Table 1).

In all studies the analytic sensitivity and specificity for each tested genotype were $100 \%$ and no lower than $94.12 \%$ (with the exception of Schaeffeler et al., ${ }^{36}$ reporting sensitivity of $91.67 \%$ to detect the duplication/(single copy) genotype and specificity of $99.79 \%$ ). However, only 26 of about 100 known CYP2D6 polymorphisms (http://www.cypalleles.ki.SE/) were evaluated in the included studies, most of which focused on only a handful of these variants.

Quality control procedures included the integration of negative and positive controls into the genotyping process in most studies $^{29,36-39}$ to ensure that results fell within the specified 
Table 1

Synopsis of evidence for key questions

\begin{tabular}{|c|c|c|c|}
\hline Key question & Number of studies & Quality & Key findings \\
\hline 1. Analytic validity & $\begin{array}{l}\text { CYP2D6 ( } 9 \text { studies), CYP2C19 } \\
\text { (3 studies), CYP2C8 (2 studies), } \\
\text { CYP2C9 (1 study), CYP1A1 (1 study) }\end{array}$ & $\begin{array}{l}\text { Mostly methods comparisons, } \\
\text { only } 4 \text { studies compared to gold } \\
\text { standard }\end{array}$ & $\begin{array}{l}\text { High sensitivity and specificity, few of known variants } \\
\text { tested, wide confidence intervals because of few } \\
\text { samples tested }\end{array}$ \\
\hline $\begin{array}{l}\text { 2. CYP genotypes and } \\
\text { metabolism of SSRIs }\end{array}$ & $\begin{array}{l}5 \text { studies of single dose of SSRIs in healthy } \\
\text { adults, } 11 \text { studies in clinical patients }\end{array}$ & $\begin{array}{l}\text { Poor to fair quality of evidence in } \\
\text { small samples, heterogeneous } \\
\text { studies }\end{array}$ & $\begin{array}{l}\text { Single dose studies showed slower metabolism of } \\
\text { SSRIs in PMs compared to EMs. Studies in clinical } \\
\text { samples showed mixed results with respect to } \\
\text { CYP2D6/CYP2C9/CYP2C19 polymorphisms and } \\
\text { SSRI blood levels. }\end{array}$ \\
\hline $\begin{array}{l}\text { 3. CYP450 Testing and } \\
\text { Efficacy of SSRIs }\end{array}$ & $\begin{array}{l}3 \text { cohort studies of depressed patients on } \\
\text { antidepressant treatment, } 2 \text { prevalence } \\
\text { studies of PMs in SSRI non responders }\end{array}$ & $\begin{array}{l}\text { Poor to fair quality of evidence in } \\
\text { small samples, heterogeneous } \\
\text { studies }\end{array}$ & $\begin{array}{l}\text { Mixed results with the first three finding no } \\
\text { difference between PMs and EMs with respect to } \\
\text { response to antidepressants, and the last two } \\
\text { studies finding higher prevalence of PMs in } \\
\text { antidepressant non-responders compared to the } \\
\text { general population }\end{array}$ \\
\hline $\begin{array}{l}\text { 4. CYP450 Testing and } \\
\text { Adverse Drug } \\
\text { Reactions }\end{array}$ & $\begin{array}{l}4 \text { cohort studies in depressed patients on } \\
\text { antidepressant treatment, } 2 \text { prevalence } \\
\text { studies of PMs in patients with adverse } \\
\text { reactions to SSRIs }\end{array}$ & $\begin{array}{l}\text { Poor to fair quality of evidence in } \\
\text { small samples, heterogeneous } \\
\text { studies }\end{array}$ & $\begin{array}{l}3 \text { cohort studies showed no difference between PMs } \\
\text { and EMs with respect to adverse effects, one } \\
\text { showed PMs to have more adverse effects, } \\
\text { particularly if they had a certain variant of } \\
\text { serotonin receptor gene. The two prevalence } \\
\text { studies found higher prevalence of PMs in patients } \\
\text { with SSRI adverse effects than in the general } \\
\text { population }\end{array}$ \\
\hline $\begin{array}{l}\text { 5. CYP testing and } \\
\text { clinical outcomes in } \\
\text { depression }\end{array}$ & No studies identified & & \\
\hline
\end{tabular}

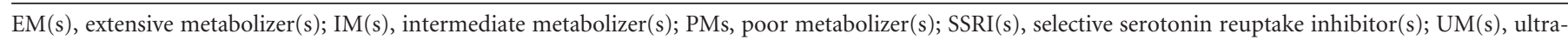
rapid metabolizer(s).

assay limits. Robustness and effect of preanalytic and analytic measures were not measured and reported by all studies.

CYP2C19. We identified three reports that compared clinical methods for genotyping CYP2C19 polymorphisms with a reference standard. Only one study ${ }^{30}$ provided a comparison with the gold standard, DNA sequencing.

All three studies reported a high sensitivity and specificity (96.43-100\%). However, each study focused on detection of two of the three common CYP2C19 alleles $\left({ }^{*} 2,{ }^{\star} 3\right.$ and $\left.{ }^{*} 4\right)$. Quality control procedures varied across studies. ${ }^{31}$

Other CYPs, and gene duplication and deletion. We identified one report that compared clinical methods for genotyping CYP2C9 polymorphisms with a reference standard. ${ }^{40} \mathrm{We}$ identified two studies that compared methods for CYP2C8 polymorphisms,${ }^{41,42}$ and one for CYP1A1 polymorphisms ${ }^{43}$ with a reference standard. All of these studies had very high sensitivity $(100 \%)$ and specificity (100\%). Gene deletion and duplication studies had lower sensitivity and specificity, further compounded by the limitation that there is no accepted gold standard for such tests. ${ }^{31}$

\section{Question 2: How well do particular CYP genotypes predict metabolism of particular SSRIs?}

We identified 16 studies that met the inclusion criteria for this question. Five studies examined SSRI metabolism after a single dose in healthy adults,,$^{27,44-47}$ and the other 11 looked at SSRI metabolism in patients who had achieved steady state after multiple doses. ${ }^{48-58}$ Data from single-dose experiments cannot be extrapolated to long-term drug therapy, as saturation pharmacokinetics, irreversible enzyme blockade, or enzyme up- or down-regulation might change the outcome with multiple dosing. ${ }^{2,59,60}$ We therefore report only the 11 studies pertaining to prolonged drug exposure.

All 11 studies were conducted in clinical populations (with sample sizes ranging from 11 to 146) and were cross-sectional in design. Sufficient data for calculating confidence intervals for differences in mean SSRI levels between homozygous EM and comparator groups (PM, heterozygous EM, etc.) were available for four studies of paroxetine, four of fluoxetine, and one of fluvoxamine (Table 2). The results for paroxetine and fluoxetine were at variance, with some studies reporting significant differences and others failing to identify such associations. The studies were typically small, resulting in wide confidence intervals (Table 1). For fluoxetine, two studies ${ }^{52,56}$ showed a significant difference in mean active moiety levels between CYP2C9 EMs and PMs, but failed to show such differences between EMs and PMs of CYP2D6 (Table 3; data for Scordo et al. ${ }^{56}$ are not shown, as results were reported as median and range rather than as means \pm standard deviation).

Notably, there were several methodological limitations in the identified studies; quality scores ranged from $3 b$ to 4 (nonconsecutive cohort study, or very limited population, or case series).

The overall quality grade for evidence regarding this question was "C" (level 4 studies or extrapolations from level 2 or 3 studies). In addition to very small samples sizes, studies were 
Table 2

Confidence intervals for differences in mean SSRI levels between extensive metabolizers (EMs) and comparison groups

\begin{tabular}{|c|c|c|c|c|c|c|c|}
\hline SSRI/CYP enzyme & Study & $\begin{array}{c}\text { Mean drug } \\
\text { concentration, EM } \\
\text { group }\end{array}$ & $\begin{array}{c}\text { Mean drug } \\
\text { concentration, } \\
\text { comparator group } \\
\text { (PM, heterozygous } \\
\text { EM, etc.) }\end{array}$ & $P$ & $\begin{array}{c}\text { Confidence } \\
\text { interval }{ }^{61} \text { for } \\
\text { difference in mean } \\
\text { drug concentration }\end{array}$ & Dose & Comments \\
\hline \multirow[t]{4}{*}{ Paroxetine/2D6 } & $\begin{array}{l}\text { Charlier et al., } \\
2003^{49}\end{array}$ & $\begin{array}{l}20.97 \pm 21.17 \mu \mathrm{g} / \mathrm{L} \\
\quad(n=30)\end{array}$ & $\begin{array}{l}72.50 \pm 29.65 \mu \mathrm{g} / \mathrm{L} \\
\quad(n=6)\end{array}$ & 0.00001 & 31.40 to 71.66 & $20 \mathrm{mg} / \mathrm{d}$ & - \\
\hline & $\begin{array}{l}\text { Sawamura et al., } \\
2004^{55}\end{array}$ & $\begin{array}{l}2.99 \pm 3.52 \mathrm{ng} / \mathrm{mL} \\
\quad(n=16)\end{array}$ & $\begin{array}{l}7.30 \pm 6.11 \mathrm{ng} / \mathrm{mL} \\
\left({ }^{\star} 1^{\star} 10 \text { or }{ }^{\star} 10^{\star} 10\right) \\
(n=35)\end{array}$ & 0.019 & 1.04 to 7.58 & $10 \mathrm{mg} / \mathrm{d}$ & $\begin{array}{l}\text { No difference at higher } \\
\text { doses, data not } \\
\text { provided }\end{array}$ \\
\hline & $\begin{array}{l}\text { Murphy et al., } \\
2003^{53}\end{array}$ & $\begin{array}{c}71.65 \pm 52.55 \mathrm{ng} / \\
\mathrm{mL}(n=105) \\
(\mathrm{EM}+\mathrm{UM})\end{array}$ & $\begin{array}{l}99.51 \pm 37.35 \mathrm{ng} / \\
\mathrm{mL}(\mathrm{IM}+\mathrm{PM}) \\
(n=15)\end{array}$ & NR & -0.15 to 55.87 & $\begin{array}{c}\text { Mean } 30.21 \mathrm{mg} / \mathrm{d} \\
(\mathrm{EM}), 26.67 \\
\mathrm{mg} / \mathrm{d}(\mathrm{PM})\end{array}$ & $\begin{array}{l}(\mathrm{EM}+\mathrm{UM}), \\
\quad(\mathrm{IM}+\mathrm{PM}) \text { groups } \\
\text { combined to } \\
\text { increase power }\end{array}$ \\
\hline & Ueda et al., $2006^{58}$ & $\begin{array}{c}150.9 \pm 20.6 \mathrm{ng} / \\
\mathrm{mL} / \mathrm{mg} / \mathrm{kg} \\
(n=17)\end{array}$ & $\begin{array}{r}76.7 \pm 6.1 \mathrm{ng} / \mathrm{mL} / \\
\mathrm{mg} / \mathrm{kg}(n=12)\end{array}$ & NR & -86.45 to 61.95 & $30 \mathrm{mg} / \mathrm{d}$ & $\begin{array}{l}\text { IM level greater than } \\
\text { EM or PM, no } \\
\text { difference at other } \\
\text { doses }\end{array}$ \\
\hline \multirow[t]{3}{*}{ Fluoxetine/2D6 } & $\begin{array}{l}\text { Charlier et al., } \\
2003^{49}\end{array}$ & $\begin{array}{l}49.4 \pm 40.7 \mu \mathrm{g} / \mathrm{L} \\
\quad(n=10)\end{array}$ & $\begin{array}{l}178.5 \pm 68.6 \mu \mathrm{g} / \mathrm{L} \\
\quad(n=2)\end{array}$ & 0.004 & 60.83 to 197.37 & $20 \mathrm{mg} / \mathrm{d}$ & $\begin{array}{l}\text { Reported fluoxetine } \\
\text { only }\end{array}$ \\
\hline & Eap et al., $2001^{50}$ & $\begin{array}{c}55 \pm 30 \mathrm{ng} / \mathrm{mL} \\
(n=6)\end{array}$ & $\begin{array}{l}104 \pm 8 \mathrm{ng} / \mathrm{mL} \\
\quad(n=3)\end{array}$ & NR & 12.82 to 85.18 & $20 \mathrm{mg} / \mathrm{d}$ & $\begin{array}{l}\text { Reported fluoxetine } \\
\text { only }\end{array}$ \\
\hline & $\begin{array}{l}\text { LLerena et al., } \\
2004^{52}\end{array}$ & $\begin{array}{c}13.0 \pm 7.6 \mathrm{nmol} / \mathrm{L} / \\
\mathrm{mg}(n=41)\end{array}$ & $\begin{array}{l}16.7 \mathrm{nmol} / \mathrm{L} / \mathrm{mg} \\
\quad(n=1)\end{array}$ & NR & -11.61 to 19.01 & Dose-corrected & $\begin{array}{l}\text { Reported fluoxetine } \\
\text { only. "No significant } \\
\text { correlation found } \\
\text { between plasma } \\
\text { concentration of } \\
\text { active moiety and } \\
\text { number of active } \\
\text { genes" }\end{array}$ \\
\hline Fluoxetine/2C9 & $\begin{array}{l}\text { LLerena et al., } \\
2004^{52}\end{array}$ & $\begin{array}{l}25.1 \pm 10.1 \mathrm{nmol} / \mathrm{L} / \\
\mathrm{mg}(n=19)\end{array}$ & $\begin{array}{l}35.5 \pm 18.5 \mathrm{nmol} / \\
\mathrm{L} / \mathrm{mg}\left({ }^{\star} 1^{\star} 2\right) \\
(n=11) \\
38.6 \pm 22.1 \\
\mathrm{nmol} / \mathrm{L} / \mathrm{mg} \\
\left({ }^{\star} 1^{\star} 3\right) \\
(n=8)\end{array}$ & $\begin{array}{l}<0.05 \\
<0.01\end{array}$ & $\begin{array}{l}0.07 \text { to } 20.73 \\
1.34 \text { to } 25.66\end{array}$ & Dose-corrected & $\begin{array}{l}\text { Active moiety } \\
\quad \text { (fluoxetine }+ \\
\text { norfluoxetine). All } \\
\text { subjects were 2D6 } \\
\text { EM }\end{array}$ \\
\hline Fluvoxamine/2D6 & Ohara et al., $2003^{54}$ & $\begin{array}{l}312.7 \pm 195.3 \mathrm{ng} / \\
\mathrm{mL} / \mathrm{mg} / \mathrm{kg} \\
(n=13)\end{array}$ & $\begin{array}{c}321 \pm 422.1 \mathrm{ng} / \mathrm{mL} / \\
\mathrm{mg} / \mathrm{kg}(n=15)\end{array}$ & 0.984 & -245.79 to 262.39 & Dose-corrected & $\begin{array}{l}\text { PM defined as } 2 \text { D6 } \\
{ }^{\star} 10^{\star} 10 \text {; EM defined } \\
\text { as no }{ }^{\star} 10 \text { (any allele } \\
\text { which was not }{ }^{\star} 3,{ }^{\star} 4 \text {, } \\
{ }^{\star} 5 \text { or }{ }^{\star} 10 \text { was } \\
\text { defined as wild-type) }\end{array}$ \\
\hline
\end{tabular}

EM, extensive metabolizer; IM, intermediate metabolizer; NR, not reported; PM, poor metabolizer; UM, ultra-rapid metabolizer.

heterogeneous with regard to the study population, the SSRIs considered, and the CYP450 polymorphisms assessed. Only one study ${ }^{52}$ took into account the possibility that more than one CYP enzyme might be involved in the metabolism of a certain SSRI. For fluoxetine, which has an active metabolite, only two studies measured active moiety (parent drug + active metabolite) rather than parent drug alone, ${ }^{52,56}$ whereas two others did not. ${ }^{49,50}$ Except for one, ${ }^{48}$ most studies accounted for comedications that may be inhibitors or substrates for the enzyme being studied. Benzodiazepines were typically allowed in these psychiatric cohorts, as these drugs are metabolized mainly by CYP3A4 and have no influence on the enzymes studied. One study ${ }^{51}$ combined SSRIs and other antidepressants and examined effects of polymorphisms of various CYP enzymes. Combining various SSRIs and SSRIs with other antidepressant medications may have confounded results because of variability in contribution of different CYP enzymes to metabolism of different SSRIs and other antidepressants, and variability in CYP inhibition by different SSRIs.

Question 3: How well does CYP450 testing predict drug efficacy?

We identified only five studies that examined the association between CYP450 genotypes and SSRI efficacy. All studies were cross-sectional in design. All five studied CYP2D6 polymorphisms, and one tested additionally 2C9 and 2C19 polymorphisms. Three studies examined depressed patients taking SSRI antidepressant treatment (Table 3) and did not show a consistent relationship between CYP450 genotype and antide- 
Table 3

CYP450 predicted phenotypes and efficacy of SSRIs

\begin{tabular}{|c|c|c|c|c|c|}
\hline Study/design & Patient characteristics & SSRI(s) & Alleles of interest & Predicted phenotypes & Results \\
\hline $\begin{array}{l}\text { Gerstenberg et al., } \\
2003^{62} \text { Cross- } \\
\text { sectional study }\end{array}$ & $\begin{array}{l}49 \text { Japanese patients } \\
\text { with depression }\end{array}$ & $\begin{array}{l}\text { Fluvoxamine (50 mg } \\
\text { 1st week, } 100 \mathrm{mg} \\
\text { 2nd week, and } 200 \\
\text { mg in remaining } 4 \\
\text { weeks) }\end{array}$ & $2 \mathrm{D} 6{ }^{\star} 1,{ }^{\star} 3,{ }^{\star} 4,{ }^{\star} 5,{ }^{\star} 10$ & $\begin{array}{l}\mathrm{EMs}=25 \% ; \mathrm{IMs}=55 \% \\
\quad \mathrm{PMs}=20 \%\end{array}$ & $\begin{array}{l}\text { Final MADRS score, } \% \\
\text { improvement, amelioration } \\
\text { score, and proportion of } \\
\text { responders not significantly } \\
\text { different in the } 3 \text { groups } \\
\text { (EMs, IMs, PMs). Raw data } \\
\text { and } P \text { values NR }\end{array}$ \\
\hline $\begin{array}{l}\text { Grasmader et al., } \\
2004^{51} \text { Cross- } \\
\text { sectional study }\end{array}$ & $\begin{array}{l}136 \text { depressed patients } \\
\text { ( } 70 \text { on SSRIs), } \\
\text { ethnicity NR (refers } \\
\text { to Caucasians in } \\
\text { conclusion) }\end{array}$ & $\begin{array}{l}\text { Fluvoxamine, } \\
\text { paroxetine, } \\
\text { sertraline, } \\
\text { citalopram }\end{array}$ & $\begin{array}{l}\text { CYP2C }{ }^{*} 1 \text { to } * 3 \text {, } \\
\text { CYP } 2 \text { C } 19^{*} 1 \text { and }{ }^{*} 2 \text {, } \\
2 \text { D } 6{ }^{*} 1 \text { to }{ }^{*} \text { and gene } \\
\text { duplication }\end{array}$ & NR & $\begin{array}{l}\text { Plasma concentration above or } \\
\text { below lower limit of } \\
\text { presumed therapeutic levels } \\
\text { did not predict response }(P= \\
0.082 \text { for CGI, } P=0.982 \text { for } \\
\text { HAM-D) }\end{array}$ \\
\hline $\begin{array}{l}\text { Murphy et al., } \\
2003^{53} \text { Cross- } \\
\text { sectional study }\end{array}$ & $\begin{array}{l}246 \text { with depression, } \\
\text { ethnicity NR }\end{array}$ & $\begin{array}{l}\text { Paroxetine }(n=120) \\
\quad \text { (and mirtazapine) }\end{array}$ & $\begin{array}{l}\text { 2D6: } 16 \text { alleles, deletion, } \\
\text { duplication, and }{ }^{\star} 41 \\
\text { allele }\end{array}$ & $\begin{array}{l}\text { PMs }=6.5 \% ; \mathrm{IMs}= \\
\text { 10.5\%; UMs = } 4 \% ; \\
\text { EMs }=79 \% \text { For } \\
\text { paroxetine, PM + IM } \\
(n=15,12.5 \%) \text { vs. } \\
\text { EM + UM }(n=105, \\
87.5 \%)\end{array}$ & $\begin{array}{l}\text { No differences between PM + } \\
\text { IM vs. EM + UM groups in } \\
\text { depression measures }(P \text { values } \\
\text { NR) }\end{array}$ \\
\hline
\end{tabular}

CGI, Clinical Global Impressions Scale; EM(s), extensive metabolizer(s); HAM-D, Hamilton Rating Scale for Depression; IM(s), intermediate metabolizer(s); MADRS, Montgomery-Åsberg Depression Rating Scale; NR, not reported; PMs, poor metabolizer(s); SSRI(s), selective serotonin reuptake inhibitor(s); UM(s), ultra-rapid metabolizer(s).

pressant efficacy. The remaining two studies examined the prevalence of different CYP2D6 genotypes in nonresponders to antidepressant treatment, including SSRIs. Rau et al. ${ }^{61}$ found a 3-fold increase in the frequency of CYP2D6 UMs in a group of 16 German depressed patients nonresponsive to antidepressants (only five treated with SSRIs) in comparison with the general population. Kawanishi et al. ${ }^{64}$ found a significantly greater prevalence of 2D6 UM phenotypes in nonresponders (subgroup of 81 Nordic Caucasian patients treated with 2D6 metabolized drugs) compared with the general population.

Studies of the relationship between genotype and treatment efficacy had a variety of methodological problems. Quality scores ranged between $3 \mathrm{~b}$ and 4 (nonconsecutive cohort study, or very limited population, or case series), and the overall quality grade for evidence regarding this question was " $\mathrm{C}$ " (level 4 studies or extrapolations from level 2 or 3 studies). Several specific problems deserve note. Two studies ${ }^{63,64}$ were pilot studies of the prevalence of CYP polymorphisms in nonresponders to antidepressant treatment. All the studies had very small numbers of patients in the UM groups. Second, only two studies ${ }^{53,62}$ evaluated individual SSRIs (fluvoxamine and paroxetine, respectively), whereas the others grouped the SSRIs together or with groups of other antidepressants. Combining various SSRIs together, and specifically SSRIs with other classes of antidepressant medications, may have confounded results because of variability in contribution of different CYP enzymes to metabolism of different drugs, and variability in CYP inhibition by different SSRIs. Third, the two prevalence studies considered ${ }^{61,63}$ have the obvious shortcoming of comparing CYP2D6 UM prevalence in depressed nonresponder patients to the UM prevalence in the general population. It is possible that CYP2D6 UM phenotype itself is associated with presence of severe depression that is treatment-resistant, which may have accounted for the high prevalence of this phenotype in nonresponders to antidepressant treatment. It would be more meaningful to compare prevalence rates between responders and nonresponders to a given SSRI, despite the requirement to screen a very large sample population. In addition, these two studies did not specify exclusion criteria. Finally, genetic factors affecting serotonin receptors and related pathways, membrane transporters, and signal transduction molecules may also confer important pharmacodynamic effects that impact SSRI efficacy. ${ }^{64}$ Thus, examining the impact of pharmacokinetic variability resulting from CYP450 polymorphisms on SSRI efficacy in isolation is not comprehensive or optimal.

\section{Question 4: How well does CYP450 testing predict adverse drug reactions?}

We identified nine studies that that examined the association between CYP450 genotypes and SSRI adverse drug reactions. Of these, three reported the incidence of adverse effects in PMs, but did not have a comparison group..$^{27,51,65}$ All the remaining six studies examined only CYP2D6 polymorphisms. Three of the studies reported no differences in rates of adverse effects between PMs and EMs, ${ }^{61,62,66}$ whereas a fourth ${ }^{53}$ reported no differences in adverse effects between the combined $\mathrm{PM}+\mathrm{IM}$ and $\mathrm{EM}+\mathrm{UM}$ groups. One study found a greater prevalence of gastrointestinal (GI) adverse effects in PMs compared with EMs. ${ }^{67}$ This study also found that the combination of CYP2D6 polymorphism and A-1438G polymorphism of the serotonin 5-HT2A receptor predicted GI adverse effects, such that PM + 5HT2A GG genotype and PM + 5HT2A AG genotype had a significantly greater risk of developing GI side effects 
compared with EM + 5HT2A AA genotype. Two studies ${ }^{61,68}$ found a significantly higher prevalence of PMs in depressed patients with adverse effects than in the general population. One of these ${ }^{68}$ also found the PM phenotype to be more frequent in depressed patients with adverse effects than in a random group of depressed patients. Studies that reported types of adverse effects reported a range of typical SSRI adverse effects including, but not limited to, anxiety, agitation, restlessness, nausea, GI upset, headache, sleep disturbance, and sexual dysfunction. ${ }^{61,62,66}$ The most common adverse effect reported was nausea.

The methodological limitations of these studies were similar to those identified in key question 3 above including small numbers of subjects, SSRIs and other antidepressants studied together, and comparison of adverse effect rate with that in the general population.

\section{Question 5: Does the identification of the CYP450 genotypes in} adults entering SSRI treatment for nonpsychotic depression lead to improved clinical outcomes compared with not testing?

We found no randomized trials of CYP450 genotyping to guide SSRI treatment compared with standard empirical treatment for any indication. Additionally, we did not find studies in which patients treated with SSRIs were tested for CYP450 genetic polymorphisms, and in which investigators reported on the impact of such testing on outcomes or on medical, personal, or public health decision-making. Even after relaxing our inclusion criteria to include all methods used for genotyping and all indications for SSRI treatment, we were unable to identify any studies that directly addressed any aspect of this question. In addition, we did not find any studies examining the effect of CYP genotypes on SSRI inhibition of CYP enzymes, leading to adverse effects associated with concurrent medications.

\section{DISCUSSION}

There is a paucity of evidence regarding the use of CYP450 genotyping as a guide to the management of SSRIs for patients with nonpsychotic depression with SSRIs. We identified moderately good-quality evidence regarding the operating characteristics of clinical tests used for CYP genotyping (Question 1). However, there was a paucity of high-quality clinical studies addressing the clinical questions. We did not find a single prospective study of CYP450 genotyping to guide treatment and measure subsequent clinical outcomes, or any randomized studies comparing alternative testing strategies. We did not identify any studies that examined the effects of CYP inhibition/induction together with genetic polymorphisms of CYP enzymes (e.g., to evaluate whether there is an additive effect of a CYP2D6 inhibitor medication in a CYP2D6 PM subject such that SSRI levels are higher than the levels without such an inhibitor medication in a CYP2D6 PM subject). Many studies examining the clinical outcomes of efficacy or adverse effects did not comment on blinding between treating clinicians and those responsible for interpreting results of genetic testing, or on patient blinding.

Genetic factors affecting serotonin receptors and their downstream pathways, membrane transporters, and signal transduction molecules have important pharmacodynamic effects that may affect SSRI efficacy or tolerability. ${ }^{64,69-81}$ Thus, genetic factors other than pharmacokinetic factors can impact SSRI outcomes, and it is suboptimal to examine effects of CYP polymorphisms on SSRI outcomes in isolation. Multivariable pathway analyses are rapidly emerging and may provide more information regarding the proportion of risk for poor outcomes in SSRI treatment of depression that may be attributable to a certain factor, such as CYP polymorphisms. A recent study ${ }^{82}$ searched for genetic predictors of treatment outcome in 1953 patients with nonpsychotic major depression treated with the SSRI citalopram. Sixty-eight chosen candidate genes were genotyped with 768 single-nucleotide polymorphism markers chosen to detect common genetic variation. A significant association was found between treatment outcome and the HTR2A gene, which encodes the serotonin 2A receptor. Genes primarily involved in citalopram drug metabolism are currently being studied independently by another group using the same DNA samples. These forthcoming results may begin to answer some of the questions posed in this report.

Additionally, clinical factors need to be considered when studying genetic variables affecting antidepressant response. The range of treatment response in depression spans the entire gamut, with patients experiencing anything between complete remission to a switch to mania in some bipolar patients. Spontaneous remissions are possible as well. In addition, treatment response may further be affected by multiple factors including, but not limited to, age, gender, severity of symptoms at baseline, duration of symptoms, comorbidity with other psychiatric illnesses such as personality disorders, and medication compliance. ${ }^{83}$ Because several clinical and demographic variables affect the sum total treatment response, it is challenging to discern the effect of a single genetic variation on specific measurements of treatment response. A recent review proposes ways to deal with each of these variables when designing pharmacogenetic studies in depression and may serve as a useful guide. ${ }^{84}$

Comparison of the results of available tests for CYP450 genotype with a reference standard suggests that the analytic sensitivity and specificity of available tests are generally high, although some serious concerns remain. In the evaluation of gene deletions and duplications, assessing the magnitude of the potential problem is limited by the lack of an established gold standard for gene copy number. Another concern is that few CYP450 variants were interrogated by the studies we identified, which focused particularly on the more common variants in Caucasians. Only a few studies reported performance relative to the gold standard of DNA sequencing (whether bidirectional or unidirectional); all were applied to a limited number of samples (as reflected by the wide confidence intervals calculated for analytic sensitivity and specificity); and there was no standard assessment report scheme for evaluation of quality 
control or assay robustness, preventing an objective performance evaluation of each method, as well as comparison between reports.

In depressed patients who have reached a steady-state concentration of an SSRI, the limited existing data do not demonstrate a clear correlation between CYP metabolizer status and (1) SSRI concentrations, (2) efficacy of SSRIs, or (3) tolerability of SSRIs. We did not identify any studies that addressed whether testing for CYP450 polymorphisms in adults entering SSRI treatment of depression leads to improved clinical outcomes compared with not testing.

\section{FUTURE RESEARCH}

The most salient finding of this review is the paucity of data supporting CYP450 genotyping in the clinical SSRI management of depression. Perhaps we should not have expected otherwise, given the fact that the FDA granted approval to the Roche Amplichip based on test accuracy, and not necessarily improved outcomes in a particular clinical condition. As more genetic tests gain FDA approval for technical performance, it is imperative to gather undisputable data supporting the utility of these tests in well-defined clinical populations. We propose the following types of studies to fill in the gaps in existing knowledge regarding CYP450 genotyping in the treatment of depression with SSRIs (the conceptual model that forms the basis for the proposed studies is described in detail elsewhere $\left.{ }^{31}\right)$ :

1. Studies of CYP genotyping in a large variety of populations to ascertain sensitivity and specificity of genotyping as applicable in real-world settings: it is essential that such studies explore a large range of the known possible polymorphisms functionally affecting each enzyme, refraining from focusing solely on the detection of the major alleles relevant to Caucasians and African Americans. To reliably assess the performance of these tests, the sample sizes employed must demonstrate sufficient statistical power to report results within narrow margins of confidence intervals, repeatedly and consistently concluding identical genotype calls.

2. Studies that better describe the CYP polymorphism-associated differences in the rate of metabolism of each individual SSRI in different ethnic group: these should overcome the limitations of current literature addressing this issue, such that they are adequately powered, address individual SSRIs, account for diet, and comedications, particularly CYP inhibiting or inducing drugs.

3. Multigenic pathway analysis studies that provide guidance regarding extent of variation in depression treatment response attributable to CYP enzymes and other pharmacokinetic and pharmacodynamic molecules of relevance: these models, although difficult to design because of limited statistical power, would be able to reflect gene-gene interactions, as well as gene-environment interactions of sufficient effect size.
4. Studies that could better ascertain the predictive value of CYP genotyping in depression treatment outcomes, and its impact on medical or personal decision-making: the suggested study design would be a properly sized (likely to be large) randomized trial of CYP genotyping-guided treatment versus treatment as usual. Such a trial should be in keeping with design standards aimed at minimizing bias (e.g., using intent-to-treat analysis, blinding of physicians and patients), maximizing generalizability (e.g., representative of individuals with severe nonpsychotic depression), and including meaningful outcomes (e.g., short-term treatment success, satisfaction, resource utilization). Such a study would provide answers about rates of dropouts/nonresponse in individuals who were genotyped versus those who were not. It would also provide data about treatment decisions by providers and patients, based on genotyping, and the outcome of such genotyping-guided treatment (e.g., different SSRI choices, higher starting doses in UMs or lower doses in PMs) in comparison with the current practice of "trial and error." It may also provide valuable information about harms.

5. Studies that could better examine the importance to patients of potential outcomes, such as time to response or quality of life during the early treatment of depression: a suggested study would be a utility or a "willingness-topay" model to determine value of these outcomes to patients.

Even if evidence favors all of the above individual studies, it would support rather than prove that adopting CYP450 testing would improve patient outcomes. Another approach would be to encompass multiple steps above into a randomized controlled study that would test this linkage directly. The simplest study would involve linking a specific genotype to SSRI type and dose. This would provide a direct test of the rationale provided by the foundational studies described above (i.e., when clinicians treat in a way indicated by evidence, does it make a difference?). However, such a study would not be a direct test of the utility of genotyping in clinical practice if the utility of testing is highly patient-specific and not suitable to being described by an algorithm. In an alternative design, patients would be randomized to being genotyped, without mandating that treatment be based on the results. The most pragmatic, but also the most difficult type of study would be a "practical clinical trial." 85 Rather than randomizing by patient, such a study would involve randomizing clusters (e.g., clinicians, practices, or regions) to have genotyping available (or perhaps reimbursed) or not. This would provide a test of the overarching question, "What difference does having genotyping available make in clinical practice?"

In summary, the evidence reviewed herein demonstrates the high analytic sensitivity and specificity of tests for cytochrome P450 (CYP450) genotyping, but for few of the known variants. The short list of papers addressing the key questions clearly demonstrates the lack of sufficient evidence for incorporation of any of these tests into guidelines for clinical practice. More- 
over, CYP450 genotyping may be only one of several genetic variants affecting response to antidepressant treatment, in addition to genetic variations in serotonin receptors, etc. There is a critical need to carry out research as described above. We anticipate that the issue will not be one of safety, but rather one of decreasing morbidity and thereby improving quality of life in patients with major depression. Considering the high prevalence of depressive disorders and the length of time required to determine whether a given antidepressant is successful or not, there may be a perceivable impact at the population level if even a small benefit can be demonstrated at the individual level. However, we call for extreme caution in interpreting any CYP genotyping results until prospective evidence-based research proves an unequivocal association between these variants and SSRI treatment outcomes in the treatment of MDD.

\section{ACKNOWLEDGMENTS}

Supported by the Centers for Disease Control and Prevention. The project was funded under Contract No. 290-02-0025 from the Agency for Healthcare Research and Quality, US Department of Health and Human Services.

The authors gratefully acknowledge Udita Patel and R. Julian Irvine for assistance with project management; Linda Bradley, PhD, and Glenn Palomaki, BS, BA, for assistance with the material on analytic validity, and Gurvaneet Randhawa, MD, MPH, AHRQ Task Order Officer, for overall support.

\section{References}

1. Kessler RC, Berglund P, Demler O, Jin R, et al. The epidemiology of major depressive disorder: results from the National Comorbidity Survey Replication (NCS-R). JAMA 2003;289:3095-3105.

2. Ustun TB, Ayuso-Mateos JL, Chatterji S, Mathers C, et al. Global burden of depressive disorders in the year 2000. Br J Psychiatry 2004;184:386-392.

3. Trivedi MH, Rush AJ, Wisniewski SR, Nierenberg AA, et al. Evaluation of outcomes with citalopram for depression using measurement-based care in STAR ${ }^{\star} \mathrm{D}$ : implications for clinical practice. Am J Psychiatry 2006;163:28-40.

4. MacGillivray S, Arroll B, Hatcher S, Ogston S, et al. Efficacy and tolerability of selective serotonin reuptake inhibitors compared with tricyclic antidepressants in depression treated in primary care: systematic review and meta-analysis. BMJ 2003; $326: 1014$.

5. Song F, Freemantle N, Sheldon TA, House A, et al. Selective serotonin reuptake inhibitors: meta-analysis of efficacy and acceptability. BMJ 1993;306:683-687.

6. Amsterdam JD, Fawcett J, Quitkin FM, Reimherr FW, et al. Fluoxetine and norfluoxetine plasma concentrations in major depression: a multicenter study. Am J Psychiatry 1997;154:963-969.

7. Beasley CM Jr, Bosomworth JC, Wernicke JF. Fluoxetine: relationships among dose, response, adverse events, and plasma concentrations in the treatment of depression. Psychopharmacol Bull 1990;26:18-24.

8. Bjerkenstedt L, Flyckt L, Overo KF, Lingjaerde O. Relationship between clinical effects, serum drug concentration and serotonin uptake inhibition in depressed patients treated with citalopram. A double-blind comparison of three dose levels. Eur J Clin Pharmacol 1985;28:553-557.

9. Cain JW. Poor response to fluoxetine: underlying depression, serotonergic overstimulation, or a "therapeutic window"? J Clin Psychiatry 1992;53:272-277.

10. Danish University Antidepressant Group. Paroxetine: a selective serotonin reuptake inhibitor showing better tolerance, but weaker antidepressant effect than clomipramine in a controlled multicenter study. J Affect Disord 1990;18:289-299.

11. Dufour H, Bouchacourt M, Thermoz P, Viala A, et al. Citalopram-a highly selective 5-HT uptake inhibitor in the treatment of depressed patients. Int Clin Psychopharmacol 1987;2:225-237.
12. Fichtner CG, Jobe TH, Braun BG. Possible therapeutic window for serotonin reuptake inhibitors. J Clin Psychiatry 1994;55:36-38.

13. Kelly MW, Perry PJ, Holstad SG, Garvey MJ. Serum fluoxetine and norfluoxetine concentrations and antidepressant response. Ther Drug Monit 1989;11:165-170.

14. Kuhs H, Schlake HP, Rolf LH, Rudolf GA. Relationship between parameters of serotonin transport and antidepressant plasma levels or therapeutic response in depressive patients treated with paroxetine and amitriptyline. Acta Psychiatr Scand 1992;85:364-369.

15. Laursen AL, Mikkelsen PL, Rasmussen S, Le Fevre Honore P. Paroxetine in the treatment of depression-a randomized comparison with amitriptyline. Acta Psychiatr Scand 1985;71:249-255.

16. Montgomery SA, Baldwin D, Shah A, Green M, et al. Plasma-level response relationships with fluoxetine and zimelidine. Clin Neuropharmacol 1990;(suppl 1):S71S75.

17. Tasker TC, Kaye CM, Zussman BD, Link CG. Paroxetine plasma levels: lack of correlation with efficacy or adverse events. Acta Psychiatr Scand Suppl 1989;350: 152-155.

18. Brosen K. Some aspects of genetic polymorphism in the biotransformation of antidepressants. Therapie 2004;59:5-12.

19. Obach RS, Cox LM, Tremaine LM. Sertraline is metabolized by multiple cytochrome P450 enzymes, monoamine oxidases, and glucuronyl transferases in human: an in vitro study. Drug Metab Dispos 2005;33:262-270.

20. Mandrioli R, Forti GC, Raggi MA. Fluoxetine metabolism and pharmacological interactions: the role of cytochrome p450. Curr Drug Metab 2006;7:127-133.

21. Olesen OV, Linnet K. Studies on the stereoselective metabolism of citalopram by human liver microsomes and cDNA-expressed cytochrome P450 enzymes. Pharmacology 1999;59:298-309.

22. Margolis JM, O'Donnell JP, Mankowski DC, Ekins S, et al. (R)-, (S)-, and racemic fluoxetine N-demethylation by human cytochrome P450 enzymes. Drug Metab Dispos 2000;28:1187-1191.

23. Bradford LD. CYP2D6 allele frequency in European Caucasians, Asians, Africans and their descendants. Pharmacogenomics 2002;3:229-243.

24. Bogni A, Monshouwer M, Moscone A, Hidestrand M, et al. Substrate specific metabolism by polymorphic cytochrome P450 2D6 alleles. Toxicol In Vitro 2005;19: 621-629.

25. Cai WM, Nikoloff DM, Pan RM, de Leon J, et al. CYP2D6 genetic variation in healthy adults and psychiatric African-American subjects: implications for clinical practice and genetic testing. Pharmacogenomics J 2006;6:343-350.

26. Ingelman-Sundberg M, Oscarson M, McLellan RA. Polymorphic human cytochrome P450 enzymes: an opportunity for individualized drug treatment. Trends Pharmacol Sci 1999;20:342-349.

27. Wang JH, Liu ZQ, Wang W, Chen XP, et al. Pharmacokinetics of sertraline in relation to genetic polymorphism of CYP2C19. Clin Pharmacol Ther 2001;70:42-47.

28. de Leon J. AmpliChip CYP450 test: personalized medicine has arrived in psychiatry. Expert Rev Mol Diagn 2006;6:277-286.

29. Roche Molecular Systems, Inc. US Food and Drug Administration 510(k) Substantial Equivalence Determination Decision Summary for Roche AmpliChip CYP450 microarray for identifying CYP2D6 genotype (510(k) Number k042259). December 2004. Available at: www.fda.gov/cdrh/reviews/k042259.pdf. Accessed April, 19 2006.

30. Roche Molecular Systems, Inc. US Food and Drug Administration 510(k) Substantial Equivalence Determination Decision Summary for Roche AmpliChip CYP450 microarray for identifying CYP2C19 genotype (510(k) Number k043576). January 2005. Available at: www.fda.gov/cdrh/reviews/k043576.pdf. Accessed April 19, 2006.

31. Matchar DB, Thakur ME, Grossman I, McCrory DC, et al. Testing for Cytochrome P450 Polymorphisms in Adults with Non-Psychotic Depression Treated with Selective Serotonin Reuptake Inhibitors (SSRIs). Evidence Report/Technology Assessment No. 146. (Prepared by the Duke Evidence-based Practice Center under Contract No. 290-02-0025.) AHRQ Publication No. 07-E002. Rockville, MD: Agency for Healthcare Research and Quality. January 2007. Available at: http://www.ahrq gov/downloads/pub/evidence/pdf/cyp450/cyp450.pdf. Accessed September 18, 2007.

32. Centers for Disease Control and Prevention. ACCE Model for Evaluation of Genetic Testing. Available at: www.cdc.gov/genomics/gtesting/ACCE.htm. Accessed April 6, 2007.

33. Phillips B, Ball C, Sackett D, et al. Oxford Centre for Evidence-based Medicine Levels of Evidence (May 2001). Available at: www.cebm.net/levels_of_evidence.asp\#levels. Accessed April 21, 2006.

34. Kotz S, Johnson NL, Read C. Encyclopedia of statistical sciences. Vol. 4: Icing the tails-limit theorems. New York: Wiley; 1983:352-354.

35. Hersberger M, Marti-Jaun J, Rentsch K, Hanseler E, et al. Rapid detection of the CYP2D6 ${ }^{\star} 3$, CYP2D6* 4 , and CYP2D $6 * 6$ alleles by tetra-primer PCR and of the CYP2D6* 5 allele by multiplex long PCR. Clin Chem 2000;46(8 Pt 1):1072-1077. 
36. Schaeffeler E, Schwab M, Eichelbaum M, Zanger UM. CYP2D6 genotyping strategy based on gene copy number determination by TaqMan real-time PCR. Hum Mutat 2003;22:476-485.

37. Neville M, Selzer R, Aizenstein B, Maguire M, et al. Characterization of cytochrome P450 2D6 alleles using the Invader system. Biotechniques 2002;(suppl):34-38, 40-43.

38. Soderback E, Zackrisson AL, Lindblom B, Alderborn A. Determination of CYP2D6 gene copy number by pyrosequencing. Clin Chem 2005;51:522-531.

39. Stamer UM, Bayerer B, Wolf S, Hoeft A, et al. Rapid and reliable method for cytochrome P450 2D6 genotyping. Clin Chem 2002;48:1412-1417.

40. Eriksson S, Berg LM, Wadelius M, Alderborn A. Cytochrome p450 genotyping by multiplexed real-time DNA sequencing with pyrosequencing technology. Assay Drug Dev Technol 2002;1(1 Pt 1):49-59.

41. Weise A, Grundler S, Zaumsegel D, Klotzek M, et al. Development and evaluation of a rapid and reliable method for cytochrome P450 2C8 genotyping. Clin Lab 2004; 50:141-148.

42. Muthiah YD, Lee WL, Teh LK, Ong CE, et al. A simple multiplex PCR method for the concurrent detection of three CYP2C8 variants. Clin Chim Acta 2004;349:191198

43. Wu X, Zhou Y, Xu S. Detection of CYP I Al polymorphisms with a colorimetric method based on mismatch hybridization. Clin Chim Acta 2002;323:103-109.

44. Liu ZQ, Cheng ZN, Huang SL, Chem XP, et al. Effect of the CYP2C19 oxidation polymorphism on fluoxetine metabolism in Chinese healthy subjects. $\mathrm{Br} \mathrm{J}$ Clin Pharmacol 2001;52:96-99.

45. Ozdemir V, Tyndale RF, Reed K, Herrmann N, et al. Paroxetine steady-state plasma concentration in relation to CYP2D6 genotype in extensive metabolizers. J Clin Psychopharmacol 1999;19:472-475.

46. Yu BN, Chen GL, He N, Ouyang DS, et al. Pharmacokinetics of citalopram in relation to genetic polymorphism of CYP2C19. Drug Metab Dispos 2003;31:12551259.

47. Yoon YR, Cha IJ, Shon JH, Kim KA, et al. Relationship of paroxetine disposition to metoprolol metabolic ratio and CYP2D6* 10 genotype of Korean subjects. Clin Pharmacol Ther 2000;67:567-576.

48. Berle JO, Steen VM, Aamo TO, Breilid H, et al. Breastfeeding during maternal antidepressant treatment with serotonin reuptake inhibitors: infant exposure, clinical symptoms, and cytochrome p450 genotypes. J Clin Psychiatry 2004;65:12281234.

49. Charlier C, Broly F, Lhermitte M, Pinto E, et al. Polymorphisms in the CYP 2D6 gene: association with plasma concentrations of fluoxetine and paroxetine. Ther Drug Monit 2003;25:738-742.

50. Eap CB, Bondolfi G, Zullino D, Savary-Cosendai L, et al. Concentrations of the enantiomers of fluoxetine and norfluoxetine after multiple doses of fluoxetine in cytochrome P4502D6 poor and extensive metabolizers. J Clin Psychopharmacol 2001;21:330-334.

51. Grasmader K, Verwohlt PL, Rietschel M, Dragicevic A, et al. Impact of polymorphisms of cytochrome-P450 isoenzymes 2C9, 2C19 and 2D6 on plasma concentrations and clinical effects of antidepressants in a naturalistic clinical setting. Eur JClin Pharmacol 2004;60:329-336.

52. LLerena A, Dorado P, Berecz R, Gonzalez AP, et al. Effect of CYP2D6 and CYP2C9 genotypes on fluoxetine and norfluoxetine plasma concentrations during steadystate conditions. Eur J Clin Pharmacol 2004;59:869-873.

53. Murphy GM Jr., Kremer C, Rodrigues HE, Schatzberg AF. Pharmacogenetics of antidepressant medication intolerance. Am J Psychiatry 2003;160:1830-1835.

54. Ohara K, Tanabu S, Ishibashi K, Ikemoto K, et al. CYP2D6* 10 alleles do not determine plasma fluvoxamine concentration/dose ratio in Japanese subjects. Eur J Clin Pharmacol 2003;58:659-661.

55. Sawamura K, Suzuki Y, Someya T. Effects of dosage and CYP2D6-mutated allele on plasma concentration of paroxetine. Eur J Clin Pharmacol 2004;60:553-557.

56. Scordo MG, Spina E, Dahl ML, Gatti G, et al. Influence of CYP2C9, 2C19 and 2D6 genetic polymorphisms on the steady-state plasma concentrations of the enantiomers of fluoxetine and norfluoxetine. Basic Clin Pharmacol Toxicol 2005;97:296301

57. Stedman CA, Begg EJ, Kennedy MA, Roberts R, et al. Cytochrome P450 2D6 genotype does not predict SSRI (fluoxetine or paroxetine) induced hyponatraemia. Hum Psychopharmacol 2002;17:187-190.

58. Ueda M, Hirokane G, Morita S, Okawa M, et al. The impact of CYP2D6 genotypes on the plasma concentration of paroxetine in Japanese psychiatric patients. Prog Neuropsychopharmacol Biol Psychiatry 2006;30:486-491.

59. Sindrup SH, Brosen K, Gram LF, Hallas J, et al. The relationship between paroxetine and the sparteine oxidation polymorphism. Clin Pharmacol Ther 1992;51:278-287.

60. Venkatakrishnan K, Greenblatt DJ, von Moltke LL, Schmider J, et al. Five distinct human cytochromes mediate amitriptyline $\mathrm{N}$-demethylation in vitro: dominance of CYP 2C19 and 3A4. J Clin Pharmacol 1998;38:112-121.

61. Rau T, Wohlleben G, Wuttke H, Thuerauf N, et al. CYP2D6 genotype: impact on adverse effects and nonresponse during treatment with antidepressants-a pilot study. Clin Pharmacol Ther 2004;75:386-393.

62. Gerstenberg G, Aoshima T, Fukasawa T, Yoshida K, et al. Relationship between clinical effects of fluvoxamine and the steady-state plasma concentrations of fluvoxamine and its major metabolite fluvoxamino acid in Japanese depressed patients. Psychopharmacology 2003;167:443-448.

63. Kawanishi C, Lundgren S, Agren H, Bertilsson L. Increased incidence of CYP2D6 gene duplication in patients with persistent mood disorders: ultrarapid metabolism of antidepressants as a cause of nonresponse. A pilot study. Eur J Clin Pharmacol 2004;59:803-807.

64. Cravchik A, Goldman D. Neurochemical individuality: genetic diversity among human dopamine and serotonin receptors and transporters. Arch Gen Psychiatry 2000; 57:1105-1114.

65. Allgulander C, Nilsson B. A prospective study of 86 new patients with social anxiety disorder. Acta Psychiatr Scand 2001;103:447-452.

66. Roberts RL, Mulder RT, Joyce PR, Luty SE, et al. No evidence of increased adverse drug reactions in cytochrome P450 CYP2D6 poor metabolizers treated with fluoxetine or nortriptyline. Hum Psychopharmacol 2004;19:17-23.

67. Suzuki Y, Sawamura K, Someya T. Polymorphisms in the 5-hydroxytryptamine 2A receptor and cytochromeP4502d6 genes synergistically predict fluvoxamine-induced side effects in Japanese depressed patients. Neuropsychopharmacology 2006; 31:825-831.

68. Chen S, Chou WH, Blouin RA, Mao Z, et al. The cytochrome P450 2D6 (CYP2D6) enzyme polymorphism: screening costs and influence on clinical outcomes in psychiatry. Clin Pharmacol Ther 1996;60:522-534.

69. Kirchheiner J, Nickchen K, Bauer M, Wong ML, et al. Pharmacogenetics of antidepressants and antipsychotics: the contribution of allelic variations to the phenotype of drug response. Mol Psychiatry 2004;9:442-473.

70. Serretti A, Artioli P, Quartesan R. Pharmacogenetics in the treatment of depression: pharmacodynamic studies. Pharmacogenet Genomics 2005;15:61-67.

71. Serretti A, Cusin C, Rossini D, Artioli P, et al. Further evidence of a combined effect of SERTPR and TPH on SSRIs response in mood disorders. Am J Med Genet B Neuropsychiatr Genet 2004;129:36-40.

72. Smits KM, Smits LJ, Schouten JS, Stelma FL, et al. Influence of SERTPR and STin 2 in the serotonin transporter gene on the effect of selective serotonin reuptake inhibitors in depression: a systematic review. Mol Psychiatry 2004;9:433-441.

73. Pollock BG, Ferrell RE, Mulsant BH, Mazumdar S, et al. Allelic variation in the serotonin transporter promoter affects onset of paroxetine treatment response in late-life depression. Neuropsychopharmacology 2000;23:587-590.

74. Smeraldi E, Zanardi R, Benedetti F, Di Bella D, et al. Polymorphism within the promoter of the serotonin transporter gene and antidepressant efficacy of fluvoxamine. Mol Psychiatry 1998;3:508-511.

75. Kim DK, Lim SW, Lee S, Sohn SE, et al. Serotonin transporter gene polymorphism and antidepressant response. Neuroreport 2000;11:215-219.

76. Kato M, Ikenaga Y, Wakeno M, Okugawa G, et al. Controlled clinical comparison of paroxetine and fluvoxamine considering the serotonin transporter promoter polymorphism. Int Clin Psychopharmacol 2005;20:151-156.

77. Yoshida K, Takahashi H, Higuchi H, Kamata M, et al. Prediction of antidepressan response to milnacipran by norepinephrine transporter gene polymorphisms. Am Psychiatry 2004;161:1575-1580.

78. Serretti A, Zanardi R, Rossini D, Cusin C, et al. Influence of tryptophan hydroxylase and serotonin transporter genes on fluvoxamine antidepressant activity. Mol Psychiatry 2001;6:586-592.

79. Ham BJ, Lee MS, Lee HJ, Kang RH, et al. No association between the tryptophan hydroxylase gene polymorphism and major depressive disorders and antidepressant response in a Korean population. Psychiatr Genet 2005;15:299-301.

80. Peters EJ, Slager SL, McGrath PJ, Knowles JA, et al. Investigation of serotoninrelated genes in antidepressant response. Mol Psychiatry 2004;9:879-889.

81. Serretti A, Artioli P. The pharmacogenomics of selective serotonin reuptake inhibitors. Pharmacogenomics J 2004;4:233-244.

82. McMahon FJ, Buervenich S, Charney D, Lipsky R, et al. Variation in the gene en coding the serotonin $2 \mathrm{~A}$ receptor is associated with outcome of antidepressant treatment. Am J Hum Genet 2006;78:804-814.

83. Anonymous. Practice guideline for the treatment of patients with major depressive disorder (revision). American Psychiatric Association. Am J Psychiatry 2000; 157(suppl 4):1-45

84. Serretti A, Kato M, Kennedy JL. Pharmacogenetic studies in depression: a proposa for methodologic guidelines. Pharmacogenomics J 7 August 2007;Epub ahead of print. Available at: http://dx.doi.org/10.1038/sj.tpj.6500477. Accessed September $18,2007$.

85. Tunis SR, Stryer DB, Clancy CM. Practical clinical trials: increasing the value of clinical research for decision making in clinical and health policy. JAMA 2003;290: $1624-1632$. 